\title{
ANTARCTIC PENINSULA CLIMATE OVER THE LAST 400 YEARS, DEDUCED FROM AN ICE-CORE RECORD
}

\author{
by \\ A.J. Aristarain \\ (Instituto Antárctico Argentino and Instituto Argentino de Nivología y Glaciologia (CRICYT), \\ Casilla de Correo, 330, 5500 Mendoza, Argentina) \\ J. Jouzel \\ (Laboratoire de Géochimie Isotopique/LODYC, CEA/IRDI/DESICP, \\ DPC - CEN Saclay, 91191 Gif sur Yvette Cédex, France) \\ and \\ M. Pourchet and C. Lorius \\ (Laboratoire de Glaciologie et Géophysique de l'Environnement, \\ B.P. 96, 38402 St Martin d'Hères Cédex, France)
}

\begin{abstract}
Reconstruction of the past climate of the Antarctic Peninsula is of special interest because it represents a possible link between the conditions that predominated over the Antarctic continent and those over South America, only about $1000 \mathrm{~km}$ away. From a detailed isotopic study on a core drilled on James Ross Island $\left(64^{\circ} 12^{\prime} \mathrm{S}, 57^{\circ} 40^{\prime} \mathrm{W}\right)$, including a comparison with the Orcadas temperature record (which has been available since 1904), we have recently examined the climatic changes which have occurred in this region over the last 130 years (Aristarain and others 1986).

We have now extended this isotope record back to about A.D. 1600 (dating is obtained from a glaciological model). A striking feature of the resulting climatic curve is the significant cooling, estimated at about $2^{\circ} \mathrm{C}$, which has been observed since the turn of the century, in comparison
\end{abstract}

with the warmest period of the record (around A.D. 1850). This feature, which is at odds with Northern Hemisphere temperature data, will be examined in the context of factors affecting the Antarctic Peninsula climate. These include sea-ice extent, and the relative influence of a maritime climate in the west and of a continental climate in the east, and the generally high climatic sensitivity theoretically expected in these ice-margin areas. The whole climatic curve will also be compared with other Antarctic and Southern Hemisphere records.

\section{REFERENCE}

Aristarain A J, Jouzel J, Pourchet M 1986 Past Antarctic Peninsula climate $(1850-1980)$ deduced from an ice core isotope record. Climatic Change 8(1): 69-89 